\title{
The Correlation Between Reading Interest, Grammatical Competence And Reading Comprehension
}

\author{
Alfi Nur Azizah, Gunarso Susilohadi, Hefy Sulistyawati \\ English Education Departement \\ Teacher Training and Education Faculty \\ Sebelas Maret University of Surakarta
}

Email:nurazizahalfi@rocketmail.com

\begin{abstract}
This article is aimed at discussing and reporting the result of a study about correlation between reading interest, grammatical competence and reading comprehension. The correlation was proven by the result of the study which was carried out in November 2013 at SMA Negeri in Cilacap. The sample of the study were 32 students of XI IPA 5 taken by cluster random sampling. A questionnaire was used to collect reading interest data and objective tests were used to collect grammatical competence data and reading comprehension data. Single correlation and multiple linear regression were used to analyze the data. The result analysis shows that there is a positive correlation between (1) reading interest and reading comprehension; (2) grammatical competence and reading comprehension; (3) reading interest, grammatical competence simultaneously, and reading comprehension. Thus, it cannot be neglected that reading interest and grammatical competence give contribution toward reading comprehension.
\end{abstract}

Keywords: reading interest, grammatical competence, reading comprehension

\section{INTRODUCTION}

Reading could be the most important skills especially in teaching learning process. There are several important aspects that influence reading comprehension such as interest and grammatical competence. A good reading comprehension will be achieved by having high interest on reading and good grammatical competence. Therefore, reading interest and grammatical competence effect each other to the reading comprehension.

According to Harri et al. (n.d) "reading can help you know more, improve your vocabulary and it boosts creativity". Reading as multifaceted process involving word recognition, comprehension, fluency, and motivation (Leipzig, 2001). Tytler (2010) mentions that fluency, experience and interest are some important factors that affect on reading comprehension.
Widdowson (1978: 63) says "comprehending is the ability to recognize sentences manifested through the visual medium and to associate them with their correct signification". Recognize sentences refer to recognize the language structures on the passage. Thus, interest and knowledge of language structures influence reading comprehension.

Aebersold \& Field state that reading is what happens when people look at a text and assign meaning to the written symbols in that text (1997: 15). He or she has not been reading, even if the person has pronounced every word correctly (Burns, 1984: 20). Grellet (1999: 8) defines reading as an active skill. It constantly involves guessing, predicting, checking and asking oneself questions. Thus, after reading students are expected to do reading comprehension exercises. 
DeBoer et al. (1982: 25) propose that some of the aspects of reading are word recognation, comprehension and reflection. Crowl (1997: 149) says "comprehension as the process by which we construct meaning from incoming information; it is affected by people's schemata, or existing knowledge about a topic". Meanwhile, Cronbach (1954: 503) defines comprehension as to grasp the idea behind a sentence or a paragraph, not simply to attach a meaning to each word in turn. Therefore, reading does not exist on read any signs or symbols but it means that the students know deeply what the text mean and they can widen their knowledge after reading.

So, reading comprehension in this study means person's knowledge of decoding skill in constructing meaning, understanding the material that involves of textual information, knowledge structures, or schemata, and eliciting both implicit and explicit information of the written passage.

Students should have intrinsic desire in reading which motivate themselves enjoy their reading text. It is interest that influences students to reading process. Hurlock (1978: 420) defines interest as sources of motivation which derive people to do what they want to do when they are free to choose. It is an enduring characteristic expressed by a relationship between a person and a particular activity or object (Elliot, 2000: 349). In addition, Hidi \& Anderson (in Ormrod, 2003: 399) underline that interest involves feelings such as pleasure, excitement, and liking that people pursuing a task. Witherington states interest as one's conciousness that an object, person, problem or situation has relation to $\operatorname{him}$ (1982: 122).

Thus, interest in this study is defined as one of source motivation and curiousity which impels someone to do what he likes freely in order to reach his particular goal of his activity. Interest involves some aspects such as motivation, pleasure, conciousness, attitudes and attention.

Another thing that affects reading comprehension is grammar. Ur (1996: 75) defines grammar as the way words are put together to make correct sentences. It is a careful description and analysis of the structure of a language; its sound structure, word structure, phrase and sentence structure (Burns and Broman, 1975: 331). Savignon (1997: 41) says "grammatical competence is mastery of the linguistic code, the ability to recognize the lexical, morphological, syntactic, and phonological features of a language and to manipulate these features to form words and sentences". Grammatical competence focuses on command of the language code, including such things as the rules of word and sentence formation, meanings, spelling and pronunciation. It acts to promote accuracy and fluency in second language production and increases in importance as the learner advances in proficiency (Gao in Schmeller, 2014).

Therefore, grammatical competence is defined as person's knowledge of the grammatical rules of a language and a person's proficiency or ability to promote accuracy and fluency of grammatically correct sentences in appropriate context.

From those theories, the writer underlines that reading interest and grammatical competence became crucial elements in reading comprehension. Therefore, the writer wants to find out whether there is a correlation between the reading interest, grammatical competence, and reading comprehension.

\section{RESEARCH METHODS}

The aim of the research is to find out how strong two variables or more are correlated according to correlation 
coefficient. The research methodology used by the writer was correlational method. Elliot (2000: 587) states that in a correlational research, the researcher attempts to determine if a relation exists between two or more variables. The variables involved in the research are reading interest and grammatical competence as independent variables and reading comprehension as dependent variable.

The population in this research was the second grade students of SMA Negeri in Cilacap in the academic year 2013/2014 which consist of twelve classes and the total number of the students is 322 students. The sample of the research is 32 students of XI IPA 5 taken by cluster random sampling. The research was conducted in November 2013.

The instruments used to collect the data are questionnaire and test. A questionnaire was used to collect the data of reading interest. It consists of 43 items in Indonesian language with four optional answers. Meanwhile, objective tests were used to collect the data of grammatical competence and reading comprehension. Grammatical competence test consists of 50 items but, there were 40 items of reading comprehension with multiple choice questions. Those three instruments above have previously been tried out to check the validity and realibility of the items.

The data of the research were analyzed using Pearson Product Moment Formula and Multiple Linear Regression. Pearson Product Moment Formula is used to test first hypothesis which states that there is positive correlation between reading interest and reading comprehension, and to test the second hypothesis which states that there is a positive correlation between grammatical competence and reading comprehension. Meanwhile, Multiple Linear Regression test is used to test the third hypothesis which states that there is a positive correlation between reading interest and grammatical competence simultaneously and reading comprehension.

\section{RESEARCH FINDINGS AND DISCUSSION}

From the computation of the first hypothesis, it is found out that correlation coefficient $\left(\mathrm{r}_{\mathrm{x} 1 \mathrm{y}}\right)$ between reading interest $\left(\mathrm{X}_{1}\right)$ and reading comprehension $(\mathrm{Y})$ is 0.352 and the value of $t_{0}$ is 2.058. After the $t_{o}$ is compared to the t-table at the level of significance $\alpha=0.05$ for $\mathrm{N}=32$ is 1.7 . It is shows that the value of $t_{0}(2.058)$ is higher than the value of $t_{t}(1.7) ; t_{0}(2.058)>t_{t}(1.7)$. It means that the first hypothesis that there is a positive correlation between reading interest and reading comprehension is accepted. Then, it shows that the increase of reading interest will be followed by the increase of students' reading comprehension. The coefficient of determination between $\mathrm{X}_{1}$ and $\mathrm{Y}$ is $(0.352)^{2}$ $\mathrm{x} 100 \%$. It means that $12.39 \%$ variation of reading comprehension is determined by reading interest.

From the computation of the second hypothesis, it is found that the correlation coefficient $\left(\mathrm{r}_{\mathrm{x} 2 \mathrm{y}}\right)$ between grammatical competence $\left(\mathrm{X}_{2}\right)$ and reading comprehension( $(\mathrm{Y})$ is 0.588 and the value of $t_{o}$ is 3.981. After the $t_{o}$ is compared to the $t-$ table at the level of significance $\alpha=0.05$ for $\mathrm{N}=32$ is 1.7. It is shows that $t_{0}(3.981)$ is higher than $t_{t}(1.7) ; t_{0}(3.981)>t_{t}(1.7)$. It means that the second hypothesis, that there is a positive correlation between grammatical competence and reading comprehension, is accepted. Then it shows that the increase of grammatical competence will be followed by the increase of students' reading comprehension. The coefficient of determination between $\mathrm{X}_{2}$ and $\mathrm{Y}(0.588)^{2} \mathrm{x}$ 
$100 \%$. It means that $34.57 \%$ variation of reading comprehension is determined by grammatical competence.

The computation of multiple regression in the third hypothesis testing, shows that the coefficient of $\mathrm{a}_{0}=178.862$, $\mathrm{a}_{1}=0.064$ and $\mathrm{a}_{2}=0.327$, so the multiple regression equation of $\mathrm{Y}$ on $\mathrm{X}_{1}$ and $\mathrm{X}_{2}$ becomes $\hat{Y}=178.862+0.064 X_{1}+0.327 X_{2}$. The testing of the signifance regression for $F_{o}$ is 8.267. After the value of $F_{o}$ is compared to F-table $\left(\mathrm{F}_{\mathrm{t}}\right)$ at the level of significance $\alpha=0.05$, it shows that the value of $F_{o}(8.26)$ is higher than $F_{t}(3.33) ; F_{o}(8.26)$ $>F_{t}$ (3.33). It means that the third hypotesis saying that there is a positive correlation between reading interest and grammatical competence simulataneously and reading comprehension is accepted. The coefficient of determination $\left(\mathrm{R}_{\mathrm{y} 12}{ }^{2}\right)$ is 0.3631 . It means that $36.31 \%$ variation of reading comprehension $(\mathrm{Y})$ is determined by reading interest $\left(\mathrm{X}_{1}\right)$ and grammatical competence $\left(\mathrm{X}_{2}\right)$ and $63.69 \%$ the rest is determined by other factors. Therefore, the theories which state that there is a positive correlation between reading interest and grammatical competence simultaneously and reading comprehension are proved.

The result of testing hypotheses shows that the coefficient correlation between reading interest, grammatical competence, and reading comprehension is significant and all hypotheses indicates positive correlation. The illustration of the correlation between reading interest, grammatical competence and reading comprehension can be described as follows.

Reading takes an important activity in people's life. It is because people need information, knowledge, entertainment and many others in order to reach their goal of reading. Brummitt (2012) underlines that reading comprehension is one of the pillars of the act of reading. It is the act of understanding what you are reading. Thus, it is obvious that reading relates to comprehension. Leipzig (2001) states reading as multifaceted process involving word recognition, comprehension, fluency, and motivation. It is making meaning from print and requires the readers to identify the words in print and construct an understanding of the text. Reading as stated by Cline et al. (2006: 2) is decoding and understanding text for particular reader purposes. Readers decode written text by translating text to speech, and translating directly to meaning.

Tytler (2010) points out that there are some important factors that affect on reading comprehension, namely: fluency, experience and interest. Ideally, interest will arise when the student choose the topic which he would like to read. Interest will be a great important role which encourages student to consider reading activity as his preferences so, he will enjoy during his reading process. Besides, interest is closely related to the curiosity. Renninger et al. (in Baker and Wigfield 1999: 2) define that curiosity is as the desire to read about a particular topic of interest to the child. It means, students who have interest in reading will have high curiosity. Baker and Wigfield (1999: 1) say that interest relates to text comprehension and other important reading outcomes. It assumes that student who has interest in reading he will comprehend the text well and get the reading outcomes such as, find the main idea, the sequence ideas, the detail information, the word meaning and so on. Those reading outcomes is needed in order to develop the reading comprehension. So, the great reading interest is important to help the students obtain meaning for better reading comprehension.

Simultaneously, another aspect that influences reading comprehension is knowledge of grammar. Perfetti (2003: 2) 
defines that the components of the system of most importance for reading are phonology and grammar. Thus, grammar is needed and influential element in achieve the goal of reading. Similarly, Nellen (1998) states that grammar is an important tool in reading. It is an important tool for readers to help them see how they see. Besides, grammatical competence as stated by Gao (in Schmeller 2014) focuses on command of the language code, including such things as the rules of word and sentence formation, meanings, spelling and pronunciation. Grammatical competence enables the reader to use knowledge and skills needed for understanding and expressing the literal meaning of utterances. So, if the students do not have grammatical competence, they will get difficulties in understanding the meaning and the function of sentences in the text.

Widodo (2006) states that the ultimate goal of teaching grammar is to provide the students with knowledge of the way language is constructed so that when they are listening, speaking, reading, and writing, they have no trouble applying the language that they are learning. It means that by having grammatical competence in reading the students are easy to apply the language in their learning.

In relation to reading comprehension, it can be pointed out that there are two aspects affect on reading comprehension namely; reading interest and grammatical competence. Reading comprehension as the basic skill to construct meaning of the written text and as the measurement how deep readers' comprehension to what the text talk about. Someone willing to read more if he has interest. Interest is an individual desire which can motivate himself in liking to do his preferences. If the students have high level of interest, it means that they have high level of curiosity. Students who have high curiosity, they will be motivated to read more to develop their deep understanding in reading. They will enjoy and more active on their reading by finding main idea, noting the sequence ideas and detail information, searching the word meaning and so on. Those abilities of reading comprehension is important for the reader to understand the passage easily, effectively, and quickly.

The second aspect affects on reading comprehension is grammatical competence. Lenz (2014) mentions some factors affect reading comprehension; they are reader's knowledge of the topic, knowledge of language structures, knowledge of text structures and genres, knowledge of cognitive and metacognitive strategies, their reasoning abilities, their motivation, and their level of engagement. It is noted that knowledge of language structures or knowledge of grammar is one important factors in reading comprehension. It is impossible for students to comprehend text without grammatical competence. They will get difficulties in understanding the meaning and identifying the function of each sentence of the passage. Grammatical competence is needed by the students in order to reach their purpose of reading.

Putri (2013) proves that grammatical competence is needed by students to help them identify the subject, predicate of each sentence; define the meaning of unfamiliar words by using context clues; identify the tenses used in text. After mastering those competences, the students can find the main idea easily and answer the specific question correctly.

In reading class, the students who have high reading interest will curious and give more attention to reading material. They will more active to find out the main idea of the text, answer the question about text, define the unfamiliar word, etcetera. Moreover, good grammatical competence 
will help the students to apply the language in their learning, able to recognize word and sentence formation, and understand the function of each sentence of the text.

\section{CONCLUSIONS AND SUGGESTIONS}

From the result of the research, it can be concluded that the first hypothesis saying there is a positive correlation between reading interest and reading comprehension is accepted. The computation presents that the correlation coefficient $\left(\mathrm{r}_{\mathrm{x} 1 \mathrm{y}}\right)$ is 0.352 and the value of $t$-obtained (2.058) is higher than the value of t-table (1.7); $t_{o}(2.058)>t_{t}(1.7)$. The coefficient of determination $\left(\mathrm{r}_{\mathrm{x} 1 \mathrm{y} 2}\right)$ between reading interest $\left(\mathrm{X}_{1}\right)$ toward reading comprehension $(\mathrm{Y})$ is 0.1237 . It means that $12.37 \%$ variation of reading comprehension $(\mathrm{Y})$ is determined by reading interest $\left(\mathrm{X}_{1}\right)$ and the rest $87.63 \%$ is determined by other factors.

The second hypotheses saying there is a positive correlation between grammatical competence and reading comprehension is accepted. The computation presents that the correlation coefficient $\left(\mathrm{r}_{\mathrm{x} 2 \mathrm{y}}\right)$ between is 0.588 and the value of t-obtained (3.981) is higher than the value of t-table (1.7); $t_{o}(3.981)>t_{t}(1.7)$. The coefficient of determination $\left(\mathrm{r}_{\mathrm{x} 2} \mathrm{y}\right)$ between grammatical competence $\left(\mathrm{X}_{2}\right)$ toward reading comprehension $(\mathrm{Y})$ is 0.345 . It means that $34.56 \%$ variation of reading comprehension (Y) is determined by grammatical competence $\left(\mathrm{X}_{2}\right)$ and $65.44 \%$ the rest is determined by other factors.

The third hypotheses saying there is a positive correlation between reading interest, grammatical competence simultaneously and reading comprehension is accepted. The computation presents that coefficient correlation $\left(\mathrm{r}_{\mathrm{y} 12}\right)$ is 0.602 and the value of $F_{o}(8.267)$ is higher than the value of F-table (3.33); $F_{o}(8.267)>F_{t}$ (3.33). The coefficient of determination $\left(\mathrm{R}_{\mathrm{y} 12}{ }^{2}\right)$ is
0.3631 . It means that $36.31 \%$ variation of reading comprehension $(\mathrm{Y})$ is determined by reading interest $\left(\mathrm{X}_{1}\right)$ and grammatical competence $\left(\mathrm{X}_{2}\right)$ and $63.69 \%$ the rest is determined by other factors.

Therefore, as the implication of this research, reading interest and grammatical competence are two important variables in giving contribution to reading comprehension. Reading interest is one factor as an intrinsic desire that affects someone to concern and focus on reading. During reading he want to know what the passage talks about by applying reading comprehension strategies in order to find the main idea, identify supporting idea; both explicit and implicit information from the text, underline the unfamiliar word, answer the question tasks and so on. Teachers are expected to motivate their students to improve their reading comprehension. It can be realized by improving students' reading interest and grammatical competence. One of teacher's ways to motivate students' interest is using interesting theme and topic in teaching reading class, giving reading tasks to read any books they are interested in and hopefully the students will enjoy to join the class. Enhancing students' interest is not enough, teachers should improve students' grammatical competence. One of the solution is by giving more time in teaching grammar. Besides, the teacher can create fun teaching learning activities by using appropriate material such as jumbled sentences, scrabble, crossword and so on. Teachers are expected to master the teaching technique of reading comprehension well to achieve the goal of teaching learning process of reading successfully.

\section{BIBLIOGRAPHY}

Aebersold, Jo Ann and Field, Mary Lee. 1997. From Reader to Reading 
Teacher. Cambridge: Cambridge University Press.

Baker, Linda and Wigfield, Allan. 1999. Dimensions of Children's Motivation for Reading and Their Relations to Reading Activity and Reading Achievement from Reading Research Quarterly, 34, 452-477. Retrieved from https://www.msu.edu/ dwong/CEP9 91/CEP991Resources/Baker\%26Wig field-MotivRdng.pdf

Burns, Paul C. and Broman, Betty L. 1975. The Language Arts in Childhood Education. Chicago: Rand McNally College Publishing Company.

Burns, Paul L.et al. 1984. Teaching Reading in Today's Elementary School. Boston: Houghton Mifflin.

Brummitt, Joelle. 2012. What is Reading Comprehension?. Retrieved from http://www.k12reader.com/what-isreading-comprehension/

Cline, F. Et al. 2006. Focus Group Reactions to Three Definition of Reading (As Originally Developed Support of NARAP Goal 1).

Minneapolis, MN: National Accessible Reading Assessment Project. Retrieved from http://www.narap.info/publications/r eports/focusgroup_reading.pdf

Cronbach, Lee J. 1954. Educatioanl Psychology, third edition. New York: Harcourt Brace Jovanovich, Inc.

Crowl, Thomas et al. 1997. Educational Psychology Windows on Teaching. New York: Times Mirror Higher Education Group, Inc.

DeBoer et al. 1982. The Teaching of Reading Sixth Edition. New York: CBS College Publishing.

Elliot, Stephen N. Et al. 2000. Educational Psychology: effective teaching, effective learning. New York: The McGraw-Hill Companies, Inc.
Grellet, Francois. 1999. Developing Reading Skills. Cambridge: Cambridge University Press.

Harri, et al. n.d. How to Fit Reading Into Part of Your Life. Retrieved from http://www.wikihow.com/Fit-

Reading-Into-Part-of-Your-DailyLife

Hurlock, Elizabeth B. 1978. Child Development. Boston: McGraw-Hill, Inc.

Leipzig, Diane Henry. 2001. What Is Reading? Retrieved from $\mathrm{http}: / /$ www.readingrockets.org/article 1352

Lenz, Keith. 2014. Reading Comprehension. Retrieved from http://www.specialconnections.ku.ed $\mathrm{u} /$ ?q=instruction/reading_comprehen sion

Nellen, Ted. 1998. The Grammar of Reading. Retrived from http://www.tnellen. com/cybereng/grammar_of_reading. html

Ormrod, Jeanne Ellis. 2003. Educational Psychology: Developing Learners. New Jersey: Merrill Prentice Hall.

Perfetti, Charles A. 2003. The Universal Grammar of Reading Scientific Studies of Reading, 7(1), 3-24. Lawrence Erlbaum Associates, Inc.

Putri, Yessi Karsita. 2013. The Correlation Between Reading Interest, Grammatical Competence, and Reading Skill (A Correlational Study of the Tenth Grade Students of SMA $N 1$ Karanganyar in the Academic Year 2012/2013). Unpublished undergraduate thesis.

Savignon, Sandra J. 1997. Communivative Competence: Theory and Classroom Practice. New York: The McGraw Hill Companies.

Schmeller, Mirna E. 2013. Grammatical Competence (Michael Canale \& 
Merrill Swain). Retrieved from http://slaencyclopediaf10.wikispaces. com/

Grammatical + Competence $+\% 28$ Michael $+\mathrm{Ca}$ nale $+\% 26+$ Merrill + Swain $\% 29$

Ur, Penny. 1996. A Course in Language Teaching. Cambridge. Cambridge University Press.

Tytler, Carolyn. 2010. Factors that Affect Reading Comprehension. Retrieved from http://voices.yahoo.com/factorsaffect-reading-comprehension7178558.html?cat $=4$

Widodo, Handoyo Puji. 2006. Approches and Procedures for Teaching Grammar. Volume 5, Number $1 \mathrm{pp}$. 122-141. Retrieved from https://education. waikato.ac.nz/research/files/etpc/200 6v5n1nar1.pdf

Widdowson, H.G. 1978. Teaching Language as Communication. Oxford: Oxford University Press.

Witherington, H.Carl. Translated by M. Buchori. 1982. Educational Psychology (Psikologi Pendidikan). Bandung. Jemmars. 